https://doi.org/10.18485/iipe_euchanges.2021.ch16

\title{
EUROPEAN (IN)SECURITY \\ IN MULTIDIMENSIONAL PERSPECTIVE OR SHORT HAPPY LIFE OF THE EU
}

\begin{abstract}
Andrey FURSOV ${ }^{1}$
Abstract: Global Europe is becoming less Europe, less wealthy and less secure: global means 'everybody's', but 'everybody's' means 'nobody's'. Formally, the EU will persist. But in substance, it will be divided into inner (the 'Carolingian Europe') and outer parts.

Our world is stepping into a period of post-global macroregionalization. Among major possible macroregions, the EU is the most questionable: it lacks inner coherence; 'Europes of different speed' are unlikely to become healthy and competitive entities, especially if one remembers two possible projects of the US, which can become an alternative to 'old Europe' - a new edition of the Rzeczpospolita and neo-Ottoman Turkey. 'MacroPoland' can also be used by the Anglo-Saxons as a counterweight to Germany and the German-centred part of Europe, and as a means to isolate Russia and China from Western Europe. It is no coincidence that, having in mind the competitive weakness of the US, Great Britain left the EU and is likely to try to organize its own macroregion based on the Arab world.

While European problems connected with the macroregionalization of the world have to do with geoeconomics and geopolitics, the most serious aspects of European (in)security are determined by geoculture. Yet, the geocultural dimension of European (in)security is a cover and simultaneously a manifestation of class and social problems acquiring cultural, racial, and ethnic forms. Here we are stepping into the sphere of multiculturalist politics of Atlanticist ruling groups in Europe that make Europe less competitive on the world scale, less secure as a society, and less European and Christian as a civilization.
\end{abstract}

${ }^{1}$ Professor, Academic, INION RAN - Institute of Scientific Information on Social Sciences of the Russian Academy of Sciences, Moscow, Russia; International Academy of Science, Innsbruck, Austria; Email: rusint@bk.ru 
The main research question is: which factor is the most dangerous for the existence of the EU as a Union and as a European one?

Keywords: Europe, insecurity, globalization, macroregionalization, geoculture, elites, multiculturalism, migration.

We do like this job - to call things

by their real names.

Karl Marx

"I wish it need not have happened in my times", said Frodo.

"So do I", said Gandalf, "and so do all who live to see such times. But that is not for them to decide.

All we have to decide is what to do with the time that is given us".

J.R.R. Tolkien

The world is not as we want it to be -

this is my message. But one should not kill the messenger.

Immanuel Wallerstein

\section{I}

According to a popular saying, there is only one step from sorrow to joy and from joy to sorrow. When we look at the history of the EU during the last 30 years, it is precisely this saying which comes to mind, at least to my mind. Instead of hopes of the radiant future and euphoria of 1989-1991, today we can see the feelings of insecurity, unsafety, uncertainty. And these feelings began to develop long before the COVID-19 affair. The point of 'no return' is situated between the economic crisis of 2008 and the migration crisis of 2015. It seems that the 'happy life' of the EU, first, was imaginative or at least not so happy, and secondly, was evidently very short - a kind of a short happy life of Francis Macomber from the famous story by Ernest Hemingway. Could it be different? I doubt it strongly. The entire European history since the fall of the Roman Empire has been the struggle for unification: Charles I, the Emperor against the Pope, Charles V, the wars of Louis XIV, the Napoleonic Wars, the World War of 1914-1945. In the course of these 
attempts, two projects are distinguishable: the Guelph ('aristocratic') and the Ghibelline ('democratic') ones. Napoleon's and Hitler's abortive European Unions were of Ghibelline nature while the last one - of Guelph nature.

The initial success of the 'last EU' had to do with two factors: 1) the position of the US pushing the globalization project through; 2) the weakening and demise of the USSR as the form of historical Russia. It is no coincidence that both globalization and the EU as part and parcel of it emerged simultaneously with the demise of the USSR in 1986-1991. The famous Russian poet, diplomat, and geopolitical thinker Feodor Tyutchev wrote that, after the rise of the empire of Peter the Great in Russia, the 'empire of Charles the Great' in Europe became impossible (Tyutchev, 2003, p. 197). It is so, indeed. It was Russia who defeated both Napoleon and Hitler as the unifiers of Europe. The interest and the strength of the US and the weakness of Russia (the USSR) were the preconditions of the emergence of global Europe in the form of the EU. The new formation was planned as secure, European, global, and, of course, enjoying a secure and happy life. In the beginning, it seemed to be so indeed. But the happy life proved to be very short. As early as in the 1990s, Europe saw the first military conflicts since the end of the Second World War; we witnessed the NATO aggression against Serbia. After that rose the economic problems of the ex-Soviet zone of Eastern Europe, the crisis of 2008, the decline of West European middle class, the Islamist terror, the migration crisis, the crisis of traditional European values responsible for making Europe a distinct civilization, i.e., Christianity, labour ethics and family.

'Unionized' Europe is global Europe (or even Globoeurope). Becoming global means automatically being vulnerable to all global crisis tendencies. The global world, as it emerged in the 1980-1990s (not to confuse globalization with such old phenomena as integration and internationalization), was a highly insecure world stepping into a crisis of which the destruction of the USSR was the first and decisive act. A ticket to a brave new global world is a kind of a ticket for the Titanic. And if somebody buys one, this person must take into account, firstly, that apart from the luxurious first class there are less pleasant sections; secondly, one has to pay for any section; thirdly, there are more chances to drown together with Titanic than to be saved - the first to be saved are always the persons from the first class.

\section{II}

It is hardly arguable that the world is becoming - with greater and greater speed - not even less secure, but more insecure. Europe is a part of 
this crazy world. European (in)security can be analysed under different angles - geopolitical, geoeconomic, and geocultural. In this article, I will largely speak about the geocultural aspect of European (in)security. There are at least three reasons for that: 1) geopolitical and geoeconomics dimensions have been better and longer studied; 2) geocultural dimension is very important because it is a good cover for social, political, psychological, etc. actions that use (geo)culture both as a mask and as a weapon; 3) current geoculture is closely tied with such - anti-European, to my mind - phenomena as multiculturalism and tolerance; together with such questions as race and ethnicity it became a kind of 'red light', 'danger sign' for researchers.

Yet, I will start - shortly - with geopolitics and geoeconomy. There is a sharp contradiction between the geopolitical and geoeconomics statuses of the EU. Being a giant, from the economic point of view, (geo)politically it is characterized - as often as not - as a dwarf. At first glance, it can seem strange. But, if we look carefully and without emotions, we will see that such characteristic has a solid foundation. The strength of Western Europe used to be based on three great powers: Great Britain, France, and Germany. But Britain has left the EU; Germany, being economically the strongest European country, is actually an American protectorate - a country under various kinds of occupation: military, political, and spiritual.

De facto, the only state in Europe, which can be formally called a 'great power', is France. First, it has nuclear weapons, in fact, independent from NATO. Secondly, it has a solid, energetic base due to atomic electric stations, they provide 78\% of energy in the country (Produire une enérgie, 2019). This contrasts France to Germany, where the government and the Greens killed atomic stations. It is precisely atomic energy that is necessary, though not sufficient for state and political sovereignty. Yet France has at least two serious weak points. The first is that its political elite can function normally only on the basis of so-called Françafrique - the informal network of ties between French politicians, diplomats, businessmen and intelligence men and their counterparts in former French African colonies. France often lacks finance. For example, during François Hollande's presidentship, he had to go to Qatar to ask its Emir to help finance the French fleet in the Mediterranean for two weeks because France itself had no money for that (Cohen, 2013; La dixième arme, 2019, p. 154). The story of the Sarkozi Qaddafi affair, which cost the Libyan leader his life, is well known. The second point is that the French army is professional, but it is not enough for French geopolitical and military needs. Many voices are heard about the 
necessity to return to a conscript army. But French generals say definite 'no'. The argument is more than serious: in such a case, due to ethnic/race tensions between 'white' and 'coloured' (Arabs, Africans) segments of the French society, there would be a permanent civil war in the barracks. After all, this being taken into consideration, we can conclude that France can only formally be considered a great power and a driver of Europe - pas du tout.

One more thing became clear during the two crises - the migration crisis of 2015 and the COVID-19 crisis of 2020. It is the lack of unity that easily translates itself into a lack of security in the EU. The two crises were enough to demonstrate that. The lack of unity is also manifested in the course of the macroregionalisation of the current world (which sometimes is also called 'deglobalization'). This process led to a competition in which the EU is far from being a single entity; its different members, first, compete with each other in different regions of the planet and, secondly, try to create their own macroregions and not a common macroregion for (and of) the EU.

Thus, Great Britain, long before Brexit, was trying to organize something like AngloArabia (Wearing, 2018) - a macroregion comprising Great Britain (or at least England) and a larger part of the Middle East. France is trying to create its own macroregion with its ex-colonies in Africa. Germany is striving to perform by economic means what Hitler tried to do militarily to put Eastern Europe under control. But here, Germany is confronted by both Great Britain and the US. The Anglo-Saxons want to realize the project of neo-Rzeczpospolita as a weapon against both Russia and Germany. Another anti-Russian project of the British is the Great Turan with Turkey as its core. The two projects are tightly interconnected and directed against the so-called 'Old Europe', Russia, and China. It goes without saying that both projects undermine the security of the EU and Europe as a whole. But the most dangerous processes to European security develop in the sphere of geoculture.

\section{III}

These processes are tightly connected with demography and sinister cultural-propaganda triad 'multiculturalism - tolerance - political correctness'.

The first question is: to what extent current Europe (I mean first of all Western Europe) is ethnically Europe? Let us begin with Great Britain: here, the Immigration Act was passed in 1948. Ten years later, $75 \%$ of Britons gave their voice for stricter control of immigration (Murray, 2017, p. 15). It was precisely in 1968 when John Enoch Powell made his famous 'Rivers of 
Blood' speech. He warned the British people of the dangers and conflicts that immigration brought with it. Though Powell was supported by $74 \%$ of the population (Murray, 2017, p. 16), the shadow Prime Minister (and not so shadow paedophile) Edward Heath ousted Powell from the shadow cabinet, paving the way for 'milk snatcher' Margaret Thatcher.

Under Thatcher, and especially in the Blair years, migration was in full swing. It is no coincidence that according to the British journalist $\mathrm{A}$. N. Wilson one of the main results of Thatcher's premiership was the fact that Britain 'ceased to be anybody's home' (Wilson, 2008, p. 9). Now, the result is the following. In 2012 only $44.9 \%$ of Londoners defined themselves as 'white Britons'. In 2014, women born outside of Great Britain gave birth to $27 \%$ of children in England and Wales. Nowadays, in 23 out of 33 London's boroughs, white people constitute a minority. Also, 32 million Britons define themselves as Christians and 2.7 million as Muslims (Murray, 2017, p. 13). But as A. Einstein used to say, the world is not a quantitative notion but a qualitative one. Muslims are much more active and faithful in their religious feelings than Britons and Western Europeans in general; they are better organized and ready to engage in conflicts and violence.

Local autochthons Europeans are poisoned and frightened by the official course of the so-called 'tolerance' and multiculturalism. One of the best definitions of multiculturalism belongs to $S$. Huntington, who wrote in the book Who We Are that multiculturalism was in its essence anti-European civilization. It is basically an anti-Western ideology (Huntington, 2004, p. 171). I define tolerance as a deliberate suppression of the Europeans' will to resist the alien aggressive cultural influence. Tolerance is a kind of cultural masochism, a culture of self-victimization. Both multiculturalism and tolerance are being imposed by the Western European (Atlanticist) governments on the population, making it submit to culturally alien minorities. In case of conflicts, the authorities - be it in Great Britain or any other Western European country - take the side of Muslims, of migrants, as in the infamous case of 'Luton parade' in England in 2009, court hearings in the Old Bayly in London (Pakistani rapists) in 2011 or the 'Rotterdam affair' in 2014. One can cite hundreds of cases (Murray, 2017, pp. 237-239).

Reacting to changing ethnic and religious situations, the British ruling class makes definite steps in the direction of Islam. In April 2018, The Economist published an article Is the Caliph a Queen? with the subtitle: Muslims Consider Queen Elizabeth's Ties to the Prophet Muhammad (2018). According to the article, Elisabeth II is the descendant of the Prophet in the 43 generations. In reality, one cannot definitely state whether Elizabeth II is related to 
Muhammad or not, but it is very indicative that The Economist, which is owned by several richest families in Great Britain (including the Rothschilds), published such an article. Must we be surprised that some representatives of English aristocracy adopt Islam? It is quite understandable from the point of view of global political economy: post-Brexit England needs the Middle East, especially its Arab part as an important element of its invisible financial empire. AngloArabia is a reality. Hence the current position of the British authorities towards Muslim migrants.

The situation in Sweden is even more striking. The dominant group of migrants who have been coming to Sweden since 2015 are young men, largely illiterate. The largest part of Muslim migrants in Sweden lives in the third-largest city in the country - Malmö, comprising 30\% of its population; it is the official number, the real number is higher (Kirchick, 2017, p. 137). Present-day Sweden is a country with the largest Iraqi population after Iraq itself. Migrants do not want to work and to be integrated into Swedish society. They are often aggressive, especially towards police and women. In 2014, Sweden occupied second place in the world by such a gloomy indicator as the number of rapes per head - 6620 (in 1975, the number was 421) (Murray, 2017, p. 251).

Though migrants are very aggressive and antisemitic, certain parties, such as the Greens, support them. J. Kirchick warns about the danger of a 'red and green union'. And he is right - this summer, we saw this kind of union in the US - the BLM movement, which some observers called 'red and black fascism'. Despite migrants' behaviour, Swedish government officials support them, praising the Muslim culture at the expense of the Swedish one. Some European politicians are ready to accept aliens' rules of the game. In 2006, the Dutch Minister of Justice Piet Hein Donner said that when Muslims become a majority in the Netherlands, they would want to change the legal system onto sharia, and if they do it in a democratic way, that is OK. The fact that Muslims within two-three generations will really become a majority or, at least, a dominant minority is openly recognized. For example, in Belgium, in his speech in Europarliament (25 April, 2016), Koen Geens warned that very soon Muslims would quantitatively overcome Europeans (Stevens, Doughty). There was no reaction.

The $14^{\text {th }}$ April issue of The Economist in 2018 was devoted to Germany (Cool Germany, 2018). As one of the main achievements of the 'Merkel epoch', the magazine praised 'new German identity' - a multiethnic, multicultural, inclusive, and tolerant one (tolerant first of all to aggressive minorities). This new identity is reflected in different spheres, from sports to 
politics. During the European Cup games, the German 'national' team comprised five players from the South (in 1990, when the Germans became world champions, there were none). In 2009 Bundestag members with a 'migrant background' amounted to 3\%, while in $2017-9 \%$. The real representation percent of German citizens, who have no German roots, is $23 \%$, almost a quarter of the population. The Economist cites the book New Germans by H. and M. Münkler, who wrote with evident satisfaction that 'static Germany' with fixed (stark) national borders and old identity dissolves in the past, while a new identity is a diverse and open one (Cool Germany, 2018). At the same time, the magazine stresses that the new Germany became more alarming and nervous, full of stress. So, they fix that new identity, in contrast to the old one, brings feelings of uncertainty and nervousness, and the politics of multiculturalism, which in fact encourages migrants' aggressiveness and, hence, the destruction of the European geoculture.

On the eve of Christmas 2015, in Köln and some other German cities, there was a massive sexual assault of migrants (largely of Arab and Afghan origin) onto German women. The police could do nothing, but when some political groups like PEGIDA tried to organize a demonstration of protest to this assault, they were severely suppressed by the police. I suspect that, at that moment, the Germans had to evaluate as quite correct Thilo Sarrazin's book Germany Abolishes Itself (Deutchland schafft sich ab) published in 2010 (Sarrazin, 2010). The ex-senator and the member of the Executive Board of the Deutsche Bundesbank showed that migrants would not integrate themselves into German society because they did not want to do it in principle. Though $47 \%$ of the Germans think that Islam is alien to Germany and its culture as Sarrazin does, his own Social Democratic Party, in a cowardly-like manner, did not support him (Murray, 2017, pp. 95-96).

Even worse is the situation in France. Officially, Arabs and Africans represent not more than $12 \%$ of the French population. But there is a trick here. According to the French tradition, those who live in France for five and more years automatically become 'French'. From this point of view, as one of the most distinguished demographers of France, J.P. Gourevitch states that $32 \%$ of the French population are not really French (Gourevitch, 2019). The French philosopher R. Camus called the process of replacement of native French by Arabs and Africans 'le Grand Remplacement' (Camus, 2011). It was predicted as early as 1973 by the French writer and traveller J. Raspail in his novel Le camp des saints (Raspail, 1973). Later, in 1985, Raspail in co-authorship with the famous French demographer J.F. Dumont published an article in Le Figaro under the title Will France be French in 2015? 
(Dumont, Raspail, 1985). The authors maintained that the growth of the nonEuropean population in France constituted a grave danger for French culture and values.

French political establishment leveled Raspail and Dumont a severe if not hysterical criticism. Yet, the critique was weak and self-defeating. The ex-minister of social affairs, G. Dufoix, wrote that Raspail and Dumont gave wrong numbers of immigrants - 59000 per year. But statistics corrected her: 62 000. It was 1989. In 2006 it was 193000 and in 2013 - 235000 (Murray, 2017, p. 119). In 2016, 32.2\% of schoolchildren in France defined themselves as Christians and $25.5 \%$ as Muslims, but only $50 \%$ of non-Muslims and 22\% of Catholics fixed religion as something important to them, while for $83 \%$ of Muslim schoolchildren, religion meant a lot (Murray, 2017, p. 121). There are so many Muslims in Paris that the quantity of mosques is not enough. At the same time, many Christian churches are being closed in Paris and France as a whole.

A strikingly symbolic fact can be seen in Saint-Denis. In fact, this 93rd department of France is the suburb of Paris. According to French police, it belongs to the class of so-called 'sensitive zones', which means 'highly criminal and dangerous'. 30\% of the population are Muslims, 15\% Catholics, yet even in Catholic schools, 70\% of children are Muslims. 10\% of all mosques are concentrated in Saint-Denis (Murray, 2017, p. 110). It is also a place where Charles Martell, who in 732 defeated Arabs in the battle of Poitiers, was buried in the Basilique. When the messes are served here, they are being guarded by soldiers in full armament.

Thus, in reality, multiculturalism is the retreat of the European culture, its demise under aggressive pressure from two sides - the aliens and the governments, the North Atlantic establishment. Do these 'establishers' understand the real nature of multiculturalism and its effects? At first glance - they do. But the first glance is not always a correct one.

\section{IV}

As early as October 2010, Bundeskanzlerin Merkel publicly said in Potsdam that the politics of multiculturalism in Germany and Europe failed. In February 2011 in Munich, British Prime Minister David Cameron proclaimed the same thing; several days later, French President Nicolas Sarkozy repeated these words. The Australian and Spanish Prime Ministers J. Howard and J.M. Aznar followed the lead (Murray, 2017, p. 97). Many observes considered these confessions to be the end of multiculturalism. It 
is far from it. The politicians criticized only a concrete form of multiculturalism, not the concept and the goal itself, for which migration as a means of creation of ethnically and culturally diverse society is a kind of a sacred cow. The proof is simple: while in 2010 there came 48589 migrants to Germany, in 2015, their number rose to 1500000 (Murray, 2017, p. 123). It happened after the famous Welcoming Speech of Angela Merkel, which contrasts with the attitude of the rank-and-file Europeans to migrants, especially to those from Muslim countries. In 2013, 77\% of the Dutch expressed their negative attitude to Islam, and in 2015, 55\% said they were against the Muslim presence in the Netherlands. In France in 2015, 67\% claimed that Islamic values were incompatible with the European ones, while 73\% expressed a negative attitude towards Islam (Murray, 2017, pp. 318-319). Commenting on these statistics, D. Murray poses a question: if everybody understands that Europeans cannot become Arabs, Indians, and Africans, why should we believe that Arabs, Indians, and Africans can become Europeans? Another question should be posed here as well: why globalist/Atlanticist elites have been pushing multiculturalism through despite negative results and the negative reaction of the European population at large?

There are several answers to this question, and they have to do, not with culture, but with the political economy of the capitalist world system and with the interests of dominant (ruling) classes of its North Atlantic core.

Firstly, in present conditions, the Western European governments simply have no possibilities to solve the problems arising with migration they have neither the wish or/and the will nor the means to improve the situation.

Secondly, immigration policy is a kind of a social war of the Western European bourgeoisie against their working and lower classes. By means of migration a new underclass is created. The social conflict between it and the 'locals' enlarges the space for manoeuver for the ruling class, distracts attention from class problems, and allows presenting them rather as race and culture problems. So much for the core of the capitalist system.

As for the periphery, western migration policy is also profitable for the dominant classes of this zone of the capitalist system. The most active and socially energetic, predominantly masculine part of the Global South's population leaves it. This social pressure onto dominant groups and, hence, social tension becomes weaker. Money sent by working migrants to their families in Arab and African countries helps them to survive and thus also diminish the will of the lower classes to resist local oppressors. 
Paradoxically, migration helps to reproduce most parasitic, bandit-like regimes in the Afro-Asian world. At the same time, by the very fact of their existence, working migrants help the reproduction of the Western plutocracies. By creating a new underclass, they push away, replace European local classes. The same politics is, in fact, promised by the new semi-legitimate president of the US, J. Biden. Having less developed class consciousness than the European working and lower classes, and being ready to work for much lesser money, they, in fact, lower vertical class tension, supplanting it by horizontal infraclass tension, which takes the form of ethnic, race, or religious conflicts. And here, dominant classes are on the side of the less-paid migrants defending their positions with 'multiculturalism' and 'tolerance' as political technologies.

But every acquisition is a loss, and every loss is an acquisition. Being a kind of solution in the short run, the migration policy cum multiculturalism brings grave medium and long-term problems which the Western European governments will not be able to solve; they can just postpone them in the manner of Hatter in 'Alice in Wonderland'. Class conflict will emerge, but in much acute form - racial and ethnic one. The only question is timing.

In 1974 in his speech at the UN General Assembly, the Algerian President Houari Boumediene said prophetic words: 'The day will come when millions of people will leave the Southern Hemisphere to burst into the Northern one. But they will do it not as friends. They will come as conquerors and will conquer this hemisphere by means of such weapons as their children. Victory will come to us from the wombs of our women' (Fallaci, 2006, p. 256). We are witnessing today what Boumediene spoke of almost half a century ago. But - and this should be definitely added 'Boumediene's programme' is implemented not by Afro-Asian hordes all by themselves, but by Atlantic transnational elites using migrant hordes as their instrument.

\section{V}

And here, we may encounter one more thing, which explains us both multiculturalism and migration policy (and migration as an ethnic or mass migration weapons) (Greenhill, 2010). The clue is given to us by two representatives of globalist/Atlanticist elites - Obama, for example. During his visit to London in 2011, Obama said that the $21^{\text {st }}$ century might be the time of the formation of new nations (The White House, 2011). Nowadays, the only means of formation of new nations is a mixture of old ones. So with 
the migration and migration crisis, we face a deliberate course towards the annihilation of old European nations with their histories, historical memory, etc., and the artificial construction of new nations in Europe on a largely non-European basis. It is a kind of historical-cultural sterilization. And the main field of testing this ethnic weapon is Germany: it accepts more migrants than any other European country; $51 \%$ of its migrants are being covered by 'integration programmes' - in contrast to Sweden (34\%) or Greece (11\%) (Murray, 2017, p. 247). So, it is Germany that became the locus operandi for the social engineering experiment of constructing 'new Europeans' via 'new Germans' - the population with fragmented deethnicized and de-historized identity. But it is precisely what the Americans were planning for Germany in 1943-1945.

At the very beginning of 1943, Professor E. Huton from Harvard University proposed to change German heredity by means of forced metisization of German women (Fursov, 2020, p. 187-188). According to Huton's plan, German men - 10-12 million prisoner officers and soldiers were to be led out of Germany and confined in concentration camps. German women staying in their country were to marry soldiers of the occupation armed forces and (attention) with specially brought immigrants, a kind of ethnic weapon.

One can say: hey, it was just a crazy American professor, a bad boy from James Bond movies. Not at all. In 1944, the US President F.D. Roosevelt told his Minister of Finance G. Morgenthau (and the latter fixed it in his diary): we must either castrate all German population or treat it in such a way that it would not be able to produce people capable to act in the manner the Germans did (Fursov, 2020, p. 187).

I have a question: what is the difference between what Roosevelt said and Hitler's plan 'Ost' for the annihilation of the Russian people? According to Morgenthau's plan, Germany was to be deindustrialized, its population to be diminished to 25 million, and a significant part was to be physically destroyed. In fact, it was Stalin who saved Germany and the German people. His principle 'Hitlers come and go, but German people stay'.

So in some respects, the current globalist migration policy in Europe, especially in Germany, reproduces the features of certain American plans of 1943-1945. The difference is that the latter was directed against the Germans, against their 'spirit of Schiller' - not let to it be reborn, as Churchill is said to write in one of his letters in 1940, while current globalist plans have all Western Europeans as their target. 
All this being said, we can state that there is one more long-term aim of the ethnic-cultural transformation of Europe by globalist elites. It is also of the class nature, but, first, it is long-term; secondly, it is being implemented as social, cultural and demographic engineering eliminating European civilization and its personificators.

Some people claim that the weakness of Europeans derives from their 'tiredness of history' (in Germany, there is even an expression Geschichtsmüde), as they have no energy for patriotism, etc. But I have a question: why are some Europeans tired of History while some are not? The French, British, Western Germans are tired? OK. But why the Eastern Germans, Poles, Hungarians, Serbians and some others are not? Their history was not less, and, perhaps, even more tiresome than that of France, Britain, or the western part of Germany. The weakening of patriotism is not the result of tiredness; it is the result of deliberate politics and propaganda of globalist elites trying to supplant patriotism with cosmopolitanism. These elites are trying to deprive the Western European peoples of their historical memory, of cultural reason. Being set in motion, this process becomes total, covers the entire society, including its elites pushing into degradation not only lower, but also upper groups, the ruling class. Born and pursued by class interests, multiculturalism cum tolerance politics is being transformed into a kind of general degradation, cultural dementia.

\section{VI}

In 2018 in London was published a book by D. Andress Cultural Dementia. It begins with the words: '... recent political events place the UK, France, and the USA in a state of catastrophic cultural dementia', a kind of 'social Alzheimer'. 'Our current dementia takes the form of particular kinds of forgetting, misremembering and mistaking the past. In that sense, it is not nostalgia... Nor is it... a simple matter of amnesia. In most cases, the amnesiac is aware that they do not remember; and knowledge of that lack - and of the potential to fill it from external information - is something to cling to. The dementia sufferer is denied the comfort of knowing they do not remember' (Andress, 2018, pp. 2-3).

Dementia deprives persons (and peoples) of their anchorage in the past, in history. This is precisely what is happening with (and to) former great European powers: political attention to History is disappearing. But one should make some correction here: it is not so much disappearing as is being eliminated with different degrees of intensity - up to a frenzy, 
demonstrated by the BLM movement and its largely white curators/ masters in the US. In fact, we should speak of the deroutinization of European history, of its un-writing.

Today, it has to do, not only with the terminal phase of the systemic crisis of capitalism, but also with the crisis of the European civilization, of the West. The latter has already been transformed into PostWest; multiculturalism as 'the weapon of the strong', of globalist elites, is an important tool in and of this process. The European civilization was based on three pillars: Christianity, labour ethic, and family. Today, we definitely witness a family crisis - the number of divorces, homosexuality and other perversions, etc., is hard evidence. The Europeans prefer not to work, letting migrants do so - far from the labour ethic which gave birth to capitalism and the rise of Europe. As for Christianity, it was not even fixed in the EU Constitution. I do not even speak about such quixotic things as the integration by the Sovieto- and Russophobic Pope John Paul II of the ifu/voodoo cult into Christianity as one of its confessions - my congratulations.

The French philosopher Chantal Delsol compares a contemporary European with Icarus, having survived his fall and turned into an invalid. As she stresses, an invalid state is, first of all, present in the heads of the Europeans (Delsol, 2003, p. 46). What is important, this state is being developed and strengthened by the Western mainstream social science, by the established intellectual. They formulate the agenda and control the discourse. In his pathbreaking book The Strange Death of Europe (2017), D. Murray depicts a conference at the University of Heidelberg in which he participated. During the conference, he writes, 'the full catastrophe of modern German thought suddenly came' to him. (As a participant in many conferences across the world, I must say that we can freely change 'German' into 'French', 'British', 'American', etc. - into any country where scholarship is dominated by politically correct newspeak and where Big Brother is not outside a person's mind, but is instilled in it.) A group of academics, - writes D. Murray, - and others had gathered to discuss the history of Europe's relations with the Middle East and North Africa. It soon became clear that nothing would be learned because nothing could be said. A succession of philosophers and historians spent their time studiously attempting to say nothing as successfully as possible. The less that was successfully said, the greater the relief and acclaim. No attempt to address any idea, history or fact was able to pass without first being put through the pit-stop of the modern academy. No generality could be attempted and no specific could 
be uttered. It was not only history and politics that were under suspicion. Philosophy, ideas and language itself had been cordoned off as though around the scene of a crime. To any outsider the edges of that scene were clearly visible. The job of the academics was to police the cordons, all the while maintaining some distractions in order to at all costs prevent wanderers from stumbling back onto the terrain of ideas.

All relevant words were immediately flagged and disputed. The word 'nation' was an obvious problem. 'History' was another word that caused the immediate interruption. When someone was so unwise as to use the term 'culture', the event ground to a halt. The word had too many different connotations and disagreements around its use to be able to be used. The word itself could not be allowed to signify anything. The aim of this game - for a game it was - was to maintain the pretence of academic inquiry while making fruitful discussion impossible. As in so many academics and colleges across Europe this game continues to the satisfaction or relief of its participants, and the frustration or indifference of everybody else.

If there remains any overriding idea it is that ideas are a problem. If there is any remaining commonly held value judgement it is that value judgements are wrong. If there remains any remaining certainty, it is a distrust of certainty. And if this does not add up to an attitude: shallow, unlikely to survive any sustained onslaught, but easy enough to adopt.

Yet, most people in their lives seek some form of certainty. Religion, politics and personal relations remain among the very few ways to try to create such certainty before the chaos we see all around us. Most people outside Europe - or the cultures we have influenced - share none of these fears, distrusts or doubts. They do not distrust their own instincts or their own actions. They do not fear acting in their own interest or think that their own self-interest or the self-interest of their kind should not be furthered. They seek to further their own lives, aspire to standards of living they see others having attained. And they have, in the meantime, a whole range of ideas, often just as numerous as Europe's, which draw them to other conclusions' (Murray, 2017, pp. 224-225).

Unfortunately, this last phrase fixed that free (meaning real) scientific thought and real human life leaves Western Europe and the US and move to other places - to Latin America, India, etc. I can say that Russia now is the least politically correct and hence the freest country in many respects, including the scientific one. Is this really Der Untergang des Abendlandes? In the 1830s, Russian diplomat and geopolitical thinker Fyodor Tyutchev (he is also one of the most famous Russian poets) wrote about Austria that it 
was like Achilles with one distinction - it had heels everywhere. What happened to Europe during the last 60-70 years is Austro-Hungarization. It became the sick man of the world. It is highly insecure from within. It reminds me of the Roman Empire of the $\mathrm{V}^{\text {th }}$ century A.D. The greatest danger for it is the social union of globalist elites and the underclass of nonEuropean origin. Both are interested in the annihilation of the European civilization, of European values, of almost everything European. Europe now is in the most insecure position in its history - if its present condition can be called History. But dum spiro, spero.

\section{REFERENCES}

Andress, D. (2018). Cultural Dementia. How the West Has Lost its History and Risks Losing Everything Else. London, Apollo book.

Camus, R. (2011). Le Grand Remplacement (introduction au remplacisme global) [The Great Replacement (introduction to global replacement)]. Paris, David Reinharc.

Cohen, P. (2013, January 11). Ils ont livré la France au Qatar [They delivered France to Qatar]. Marianne, retrieved from https:/ / www.marianne.net/ politique/ils-ont-livre-la-france-au-qatar. Accessed 6 February 2021.

Delsol, C. (2003). Icarus Fallen. The Search of Meaning in an Uncertain World. London, ISI Books.

Dumont, J.F., Raspail, J. (1985). La France sera-t-elle francaise en 2015? Le Figaro.

Cool Germany. (2018, April 14), retrieved from https://www.economist. com/weeklyedition/2018-04-14. Accessed 3 February 2021.

Fallaci, O. (2006). The Force of Reason. New York, Rizzoli.

Gourevitch, J.P. (2019). Le grand remplacement, réalité ou intox [The great replacement, reality or intox]. Paris, Pierre-Guillaume de Roux.

Greenhill, K.M. (2010). Weapons of Mass Migration. Forced Displacement, coercion, and Foreign Policy. London, Carnell University Press.

Huntington, S. (2004). Who Are We? New York, Free Press.

Economist (2018, April 7). Is the Caliph a Queen? Muslims Consider Queen

Elizabeth's Ties to the Prophet Muhammad, retrieved from https://www.economist.com/middle-east-and-africa/2018/04/05/ muslims-consider-queen-elizabeths-ties-to-the-prophet-muhammad. Accessed 3 February 2021. 
Kirchick, J. (2017). The End of Europe. Dictators, Demagogues, and Coming Dark Age. London, Yale University Press.

Murray, D. (2017). The Strange Death of Europe. Immigration. Identity. Islam. London, Bloomsbury.

Produire une enérgie respectueuese du climat [Producing climate-friendly energy]. (2019), retrieved from https://www.edf.fr/groupe-edf/ produire-une-energie-respectueuse-du-climat. Accessed 6 February 2021.

Raspail, J. (1973). Le camp des saints [The camp of the saints]. Paris, Robert Laffont.

The White House. Office of the Press Secretary. (2011, May 25). Remarks by the President to Parliament in London, United Kingdom. Retrieved from https: / / obamawhitehouse.archives.gov/the-pressoffice/2011/05/25/remarks-president-parliament-london-unitedkingdom. Accessed 6 February 2021.

Sarrazin, T. (2010). Deutschland schafft sich ab: Wie wir unser Land aufs Spiel setzen [Germany is abolishing itself: How we are putting our country at risk]. München, DVA.

Stevens, J., Doughty, S. (2016, April 26). Europe 'to have more Muslims than Christians': Belgian minister warns Brussels attacks hearing that the continent should not 'make an enemy of Islam', Daily Mail, retrieved from https://www.dailymail.co.uk/news/article-3558706/EuropeMuslims-Christians.html, Accessed 6 February 2021.

La dixième arme - Quinze ans d'alertes et syntheses [The tenth weapon Fifteen years of alerts and summaries] (2019, July 1), retrieved from http:/ / stratediplo.blogspot.com/2019/07/la-dixieme-arme-quinze-ansdalertes-et.html. Accessed 6 February 2021.

Tyutchev, F.I. (2003). Россия и Запаd [Russia and the West]. Moscow, Классика.

Fursov, A.I. (2020). Водораздел. Будущее, которое уже наступило [The Watershed. The Future That Has Already Come]. Moscow, Книжный мир.

Wearing, D. (2018). AngloArabia. Why Gulf Wealth Matters to Britain. Cambridge, Polity.

Wilson, A.N. (2008). Our Times: The Age of Elisabeth II. London, Hutchinson. 